\title{
MODIFIED ATMOSPHERE PACKAGING EXTENDING THE STORAGE LIFE OF 'DOURADÃO' PEACH'
}

\author{
LIGIA REGINA RADOMILLE DE SANTANA², BENEDITO CARLOS BENEDETTI ${ }^{3}$, \\ JOSÉ MARIA MONTEIRO SIGRIST ${ }^{4}$, CLAIRE ISABEL GRÍGOLI DE LUCA SARANTOPÓULOS
}

\begin{abstract}
Douradão' peach is a perishable product and when cold stored is subject to chilling injury. The objective of the experiment was to evaluate the effect of modified atmosphere packaging (MAP) and cold storage on quality and storage life of these peaches. Fruits were packed in polypropylene (PP) trays and placed inside low density polyethylene (LDPE) bags (30,50, 60, $75 \mu \mathrm{m}$ thickness) with active modified atmosphere $\left(10 \mathrm{kPaCO}_{2}+1.5 \mathrm{kPaO}_{2}\right.$, balance $\left.\mathrm{N}_{2}\right)$. The control was made with peaches held in nonwrapped PP trays. Fruits were kept at $1 \pm 1^{\circ} \mathrm{C}$ and $90 \pm 5 \%$ relative humidity $(\mathrm{RH})$ for 28 days and $\mathrm{CO}_{2}$ and $\mathrm{O}_{2}$ within packages was monitored every two days. After 14, 21 and 28 days, samples were withdrawn from MAP and kept in air at $25 \pm 1{ }^{\circ} \mathrm{C}$ and $90 \pm 5 \% \mathrm{RH}$ for ripening. On the day of removal from the cold storage and after 4 days, peaches were evaluated for weight loss, decay incidence, flesh firmness, woolliness incidence, soluble solids content (SSC), titratable acidity (TA) and juice content. The results showed that MAP had influence on reducing weight loss and prevented postharvest decay. $\mathrm{MAP}$ of $1-2 \mathrm{kPa} \mathrm{O}_{2}$ and $3-6 \mathrm{kPa} \mathrm{CO}_{2}$ at $1{ }^{\circ} \mathrm{C}$ (from 50 and $60 \mu \mathrm{m}$ LDPE films) were effective for keeping good quality of 'Douradão' peaches during 28 days of storage, the ripe fruits showed reduced incidence of woolliness, adequate juiciness and flesh firmness. Packages of 30 and $75 \mu \mathrm{m}$ LDPE films were ineffective for reducing woolliness during cold storage. MAP fruits showed lower SSC and no relevant effect on TA. Control fruits did not present marketable conditions after 14 days of cold storage.
\end{abstract}

Index terms: Prunus persica, LDPE, chilling injury, woolliness, storage life.

\section{USO DE ATMOSFERA MODIFICADA PARA ESTENDER O PERÍODO DE ESTOCAGEM DE PẾSSEGOS 'DOURADÃO'}

\begin{abstract}
RESUMO - O pêssego 'Douradão’ é um produto perecível e, quando armazenado sob refrigeração, está sujeito à injúria pelo frio. O objetivo deste trabalho foi avaliar o efeito da embalagem de atmosfera modificada (AM) na qualidade e na extensão da vida de estocagem destes pêssegos refrigerados. Os frutos foram acondicionados em bandejas de polipropileno (PP) e colocados dentro de sacos plásticos de polietileno de baixa densidade (PEBD) com espessuras de 30; 50; 60 e $75 \mu \mathrm{m}$ e com modificação ativa da atmosfera (10 kPa $\mathrm{CO}_{2}+1.5 \mathrm{kPa} \mathrm{O}_{2}$, balance $\mathrm{N}_{2}$ ). O tratamento controle foi feito com pêssegos acondicionados em bandejas de PP sem embalagem plástica. Os frutos foram mantidos em câmara a $1 \pm 1{ }^{\circ} \mathrm{C}$ e $90 \pm 5 \%$ de umidade relativa (UR) por 28 dias, e as concentrações de $\mathrm{CO}_{2}$ e $\mathrm{O}_{2}$ dentro das embalagens foram avaliadas a cada dois dias. Após 14; 21 e 28 dias, as embalagens plásticas foram retiradas, e as amostras foram mantidas em ar a $25 \pm$ $1{ }^{\circ} \mathrm{C}$ e $90 \pm 5 \%$ UR para amadurecimento. No dia da remoção e após 4 dias, os pêssegos foram avaliados quanto a perda de massa, incidência de podridão, firmeza da polpa, incidência de lanosidade, conteúdo de sólidos solúveis (CSS), acidez titulável (AT) e teor de suco. Os resultados mostraram que as embalagens de AM tiveram influência na redução da perda de massa e preveniu a podridão dos frutos. As embalagens de AM que mantiveram concentrações de 1-2 $\mathrm{kPa} \mathrm{O}_{2}$ e $3-6 \mathrm{kPa} \mathrm{CO}_{2}$ a $1{ }^{\circ} \mathrm{C}$ (provenientes dos filmes de PEBD de 50 e $60 \mu \mathrm{m}$ ) foram efetivas para manter a boa qualidade dos pêssegos 'Douradão' durante 28 dias de estocagem, e os frutos maduros mostraram baixa incidência de lanosidade, adequada suculência e firmeza da polpa. As embalagens dos filmes de PEBD de 30 e $75 \mu \mathrm{m}$ foram ineficientes para reduzir a lanosidade nos frutos durante a estocagem refrigerada. Os frutos oriundos das embalagens de AM mostraram menor CSS e efeito não relevante sobre a AT. Os frutos-controle não apresentaram condições de comercialização após 14 dias de estocagem refrigerada.
\end{abstract}

Termos para indexação: Prunus persica, PEBD, injúria pelo frio, lanosidade, vida útil.

\footnotetext{
${ }^{1}$ (Trabalho 181-09). Recebido em: 04/08/2009. Aceito para publicação em: 22/09/2010. Parte do Projeto de Pesquisa "Conservação de pêssego cv. Dourado-2 sob atmosfera controlada", financiado pela FAPESP (Processo n.2006/03659-0).

${ }^{2}$ Profa. Dra. Departamento Ciências da Vida, UNEB/Faculdade de Nutrição, Av. Silveira Martins, n.2555, 41195-001, Salvador-BA, Brasil, E-mail: ligiarrs@ig.com.br, lrsantana@uneb.br

${ }^{3}$ Prof. Dr. Faculdade de Engenharia Agrícola-UNICAMP, C.P. 6011,13083-875, Campinas-SP, Brasil. Bolsista CNPq, PQ-2, E-mail: benedeti@agr.unicamp.br.

${ }^{4}$ Pesquisador Dr. Grupo de Engenharia e Pós-colheita- ITAL, C.P. 130, 13001-970, Campinas-SP, Brasil, E-mail: jmms@ital.sp.gov.br ${ }^{5}$ Pesquisadora MSc. Centro de Tecnologia de Embalagem- ITAL, C.P. 130, 13001-970, Campinas-SP, Brasil, E-mail: claire@ital.sp.gov.br
} 


\section{INTRODUCTION}

Peaches (Prunus persica L) ripen and deteriorate quickly at room temperature therefore cold storage is used to slow down these processes and the decay development. However, chilling injury limits the storage life of peaches under low temperature for less than two weeks in regular atmosphere. Although the fruits have a good appearance when removed from cold storage, they fail to ripen satisfactorily and become dry and mealy or woolly in texture. Reports have related that the use of modified atmospheres (MA) with elevated $\mathrm{CO}_{2}$ and reduced $\mathrm{O}_{2}$ concentrations delay or prevent the onset of these chilling symptoms and the storage life of the fruit can be extended (LURIE; CRISOSTO, 2005). Repeated attempts have been made to maintain a MA during transport of fresh product either by modification of the atmosphere in the entire transport vehicle or by overwrapping pallet units of product (HARRIS; HARVEY, 1973). Modified atmosphere packaging (MAP) has been introduced as a less expensive alternative technology to controlled atmosphere, but different results have been obtained depend on the cultivar and the final $\mathrm{CO}_{2}$ and $\mathrm{O}_{2}$ concentration attained at the steady-state (ZOFFOLI et al., 1997). Studies on MAP of peaches and nectarines have showed that MAP slowed down the respiration rate of fruits and retarded the decrease in titratable acidity values, maintained the fruit sugar and soluble solids content, flesh firmness, vitamin C and juice content, and slowed deterioration through decreasing fruit injury and browning development (DEILY; RIZVI, 1983; ZOFFOLI et al., 1998). The MA efficiency is related to cultivar, preharvest factors, temperature, fruit size, marketing period and shipping time (VON MOLLENDORFF, 1987; CRISOSTO et al., 1997; (CRISOSTO et al., 1999a). There is a large variation among different selections and/or cultivars of peaches as to their susceptibility to chilling injury when stored either at 0 or $5{ }^{\circ} \mathrm{C}$, indicating that the symptoms have a significant genetic component (CRISOSTO et al., 1999b).

The 'Douradão' peach is one of the most important cultivar grown in the state of São Paulo, Brazil. These fruits have shown preference by consumers whom have mentioned it as having the best qualitative characteristics like sweet taste, intense cover color and big size, and by traders and their clients, mainly due to the higher prices tendency. However, nonripe fruits are subject to chilling injury when exposed to cold temperature (lower than $5^{\circ} \mathrm{C}$ ) for more than 14 days. Since this disorder is not externally visible, fruits are often marketed at this stage, which can lead to decreased consumer acceptance. The objective of this work was to evaluate the effect of modified atmosphere packaging (MAP) and cold storage on quality and storage life of 'Douradão' peaches.

\section{MATERIALS AND METHODS}

Peaches (Prunus persica L) 'Douradão’ were harvested from a commercial orchard in Jarinu, São Paulo, located in the southeast of Brazil under a subtropical climate, pre-selected and transported about $80 \mathrm{~km}$ to the Postharvest Laboratory. Then, the fruits were selected according to size and skin background color at commercial maturity and immediately pre-cooled in air at $5 \pm 1{ }^{\circ} \mathrm{C}$ during 5 hours. Before pre-cooling, 72 peaches were randomly sampled and placed in 6 nonwrapped polypropylene (PP) trays (United Plastic Corporation S.A.), containing 12 peaches each, which were held in air at $25 \pm 1{ }^{\circ} \mathrm{C}$ and $90 \pm 5 \% \mathrm{RH}$ during 4 days for ripening. On the same day of harvest ( 3 trays) and on the $4^{\text {th }}$ day of ripening (3 trays, each tray constituted a replicate), the peaches were evaluated for weight loss, decay incidence, flesh firmness, woolliness incidence, soluble solids content (SSC), titratable acidity (TA) and juice content. The experiment was carried out in an entirely randomized design where fruits were randomly distributed into five lots, one was held in nonwrapped PP trays (control) kept in air and the others were placed in similar PP trays, inserted in bags of low density polyethylene (LDPE) film (Altaplast Ltda, Brazil), where gas mixture of $10 \mathrm{kPa} \mathrm{CO}_{2}$ $+1.5 \mathrm{kPaO}_{2}$ (balance $\mathrm{N}_{2}$ ) was injected and the packages were sealed, using a Selovac 200B machine (Selovac Ltda, Brazil). After sealing, the package area for gas exchange was equivalent to $0.21 \mathrm{~m}^{2} \mathrm{~kg}^{-1}$ of fruit. The following treatments were tested: $\left(\mathrm{T}_{1}\right)$ Control: nonwrapped PP trays; $\left(\mathrm{T}_{2}\right) \boldsymbol{M A 3 0}$ : LDPE film of $30 \mu \mathrm{m}$ thickness, with $\mathrm{CO}_{2}$ permeability rate at standard temperature and pressure $\left(\mathrm{CO}_{2} \mathrm{PR}\right)$ of $22.021 \mathrm{~mL} \mathrm{~m}^{-2} \mathrm{~d}^{-1}$ and $\mathrm{O}_{2}$ permeability rate at standard temperature and pressure $\left(\mathrm{O}_{2} \mathrm{PR}\right)$ of $6.012 \mathrm{~mL}$ $\mathrm{m}^{-2} \mathrm{~d}^{-1}$. The water vapor permeability rate (WVPR) at $38{ }^{\circ} \mathrm{C}$ and $90 \%$ RH was $14.1 \mathrm{~g}$ water $\mathrm{m}^{-2} \mathrm{~d}^{-1} .\left(\mathrm{T}_{3}\right)$ MA50: LDPE film of $50 \mu \mathrm{m}$ thickness, with $\mathrm{CO}_{2}$ PR of $11.562 \mathrm{~mL} \mathrm{~m}^{-2} \mathrm{~d}^{-1}$ and $\mathrm{O}_{2}$ PR of $2.986 \mathrm{~mL} \mathrm{~m}^{-2}$ $\mathrm{d}^{-1}$. The WVPR was $6.6 \mathrm{~g}$ water $\mathrm{m}^{-2} \mathrm{~d}^{-1} .\left(\mathrm{T}_{4}\right) \boldsymbol{M A 6 0}$ : LDPE film of $60 \mu \mathrm{m}$ thickness, with $\mathrm{CO}_{2}$ PR of $9.577 \mathrm{~mL} \mathrm{~m}^{-2} \mathrm{~d}^{-1}$ and $\mathrm{O}_{2}$ PR of $2.872 \mathrm{~mL} \mathrm{~m}^{-2} \mathrm{~d}^{-1}$. The WVPR was $5.9 \mathrm{~g}$ water $\mathrm{m}^{-2} \mathrm{~d}^{-1}$. $\left(\mathrm{T}_{5}\right) \boldsymbol{M A 7 5}$ : LDPE film of $75 \mu \mathrm{m}$ thickness, with $\mathrm{CO}_{2} \mathrm{PR}$ of $7.425 \mathrm{~mL}$ $\mathrm{m}^{-2} \mathrm{~d}^{-1}$ and $\mathrm{O}_{2}$ PR of $1,705 \mathrm{~mL} \mathrm{~m}^{-2} \mathrm{~d}^{-1}$. The WVPR was $4.1 \mathrm{~g}$ water $\mathrm{m}^{-2} \mathrm{~d}^{-1}$. 
All treatments were stored during 28 days at 1 $\pm 1{ }^{\circ} \mathrm{C}$ and relative humidity (RH) of $90 \pm 5 \%$. After 14. 21 and 28 days, fruits were taken from cold storage, the LDPE films removed and subsequently the trays were held in air at $25 \pm 1{ }^{\circ} \mathrm{C}$ and $90 \pm 5 \% \mathrm{RH}$ during 4 days for ripening. Quality parameters were determined on the same day of removal and on the $4^{\text {th }}$ day of ripening, as mentioned to the fruits at harvest. Three replicates per treatment were obtained to each assayed period and each tray contained 12 peaches.

Changes in $\mathrm{O}_{2}$ and $\mathrm{CO}_{2}$ inside the packages were monitored every two days during cold storage by randomly taking 4 trays from each treatment. Samples were taken from the package headspace through a septum using a gas analyzer (PBI Dansensor, Combi-check 9800-1, England) provided with a paramagnetic sensor for oxygen analyzer and an infrared sensor for carbon dioxide. The analyzer was standardized using air and a mixture of $1.5 \mathrm{kPa} \mathrm{O}_{2}$ and $10 \mathrm{kPa} \mathrm{CO}_{2}$ (balance $\mathrm{N}_{2}$ ). To avoid modifications in the headspace gas composition, due to gas sampling, each package was used only for a single determination of the gas composition.

Weight loss during storage was expressed as percentage of initial mass. The decay incidence (DI) was determined visually (adapted from BASSETTO, 2006) in the fruits from three trays and rated as $0=$ absent; $1=$ very slight $(1 \% \leq$ surface $\leq 10 \%) ; 2=$ slight $(10 \%<$ surface $\leq 25 \%) ; 3=$ moderate $(25 \%<$ surface $\leq 50 \%) ; 4=$ severe $(50 \%<$ surface $\leq 100 \%)$. Healthy fruits were those showing no signs of decay. The DI was calculated as follow: $\mathrm{DI}=$ (number of healthy fruit $\mathrm{x} 0)+($ number of fruits with very slight decay x 1$)+$ (number of fruits with slight decay x 2) + (number of fruits with moderate decay x 3 ) + (number of fruits with severe decay $\times 4)$, divided by $4 \times \mathrm{N}(\mathrm{N}=$ total number of fruits).

On each day of evaluation, ten fruits were randomly removed from three trays to determination of ripeness characteristics. The fruits were cut into two halves and the woolliness incidence (WI) was determined visually in both sides (adapted from FERNÁNDEZ-TRUJILLO et al., 1998) and rated as very slight $(1 \%<$ area $\leq 10 \%)$, slight $(10 \%<$ area $\leq$ $25 \%)$, moderate $(25 \%<$ area $\leq 50 \%)$ or severe (area $>50 \%$ ). Healthy fruits were those showing no signs of internal breakdown. The WI was calculated as mentioned for decay incidence.

The flesh firmness was measured on two opposite sides of each fruit using a TAXT-2 Texture Analyser (Stable Micro Systems LTD, England) at room temperature, equipped with a $8 \mathrm{~mm}$ tip diameter plunger, operating with the following conditions: $5.0 \mathrm{~mm} \mathrm{~s}^{-1}$ pre-test speed, $1.0 \mathrm{~mm} \mathrm{~s}^{-1}$ test speed, $5.0 \mathrm{~mm} \mathrm{~s}^{-1}$ post-test speed, $9 \mathrm{~mm}$ depth and 25\% strain (ASAE, 2000).

Segments from each fruit were homogenized using a commercial blender (Philips) and soluble solids content $\left({ }^{\circ}\right.$ Brix $)$ was measured with a hand refractometer (Atago, model N1 $\alpha$, Japan). Titratable acidity was determined by titrating $10 \mathrm{~g}$ of the homogenized pulp with $0.01 \mathrm{~N} \mathrm{NaOH}$ to an endpoint of $\mathrm{pH} 8.1$ (Micronal Titrator, model B274, Brazil), the results were expressed as $\mathrm{g}$ of malic acid in $100 \mathrm{~g}^{-1}$ fresh weight (AOAC, 1995). The amount of extractable juice was determined using a refrigerate centrifuge (Sorvall, RMC14, USA), where $1.5 \mathrm{~g}$ of homogenized pulp from each fruit was transferred into an Eppendorf tube and centrifuged at 6,000 x g during $15 \mathrm{~min}$, the weight of the supernatants was expressed as a percentage of the weight of the fresh fruit (adapted from VON MOLLENDORFF; De VILLIERS, 1988).

An ANOVA for quality attributes was performed (F-test) and the treatment averages were compared by the Tukey multiple range test at $\mathrm{p} \leq$ 0.05 , using the SAS statistical package (SAS, 2003). The values at harvest and after each storage period were compared to find significant differences among treatments. The percentage data for the variable woolliness and decay incidence were normalized according to the equation $\mathrm{f}(\mathrm{x})=\operatorname{arcsine}(\mathrm{x}+0.5)^{1 / 2}$.

\section{RESULTS AND DISCUSSION}

Significant differences in the $\mathrm{O}_{2}$ and $\mathrm{CO}_{2}$ concentrations were detected among the treatments during the cold storage period (Figure 1 and 2). An excessive increased in $\mathrm{O}_{2}$ and a decrease in $\mathrm{CO}_{2}$ level (about 99\%) for the treatment MA30 were found and an atmosphere similar to the air $\left(17 \mathrm{kPa} \mathrm{O}_{2}\right.$ and $0.03 \mathrm{kPa} \mathrm{CO}_{2}$ ) within the packages was obtained, due to high $\mathrm{O}_{2}$ and $\mathrm{CO}_{2}$ permeability rate. No significant differences were detected in $\mathrm{O}_{2}$ level in the MA50 treatment and the $\mathrm{O}_{2}$ concentration was maintained at $2 \mathrm{kPa}$. Although a decrease in $\mathrm{CO}_{2}$ level (about $65 \%$ ) within these packages was verified, the $\mathrm{CO}_{2}$ partial pressure was maintained at 4-3 $\mathrm{kPa}$ until the end of cold storage. A decrease in $\mathrm{O}_{2}$ (about $33 \%$ ) and $\mathrm{CO}_{2}$ (about 40\%) levels within $60 \mu \mathrm{m}$ LDPE packages were verified. The $\mathrm{O}_{2}$ partial pressure was maintained at $1 \mathrm{kPa}$ and the $\mathrm{CO}_{2}$ partial pressure was about $6 \mathrm{kPa}$ until the end of cold storage. Both package systems (MA50 and MA60) attended to the recommended level for MAP peaches mentioned by Kader (1997) and were adequate to pack 'Douradão' peaches, since they had proper $\mathrm{O}_{2}$ and $\mathrm{CO}_{2}$ permeability at cold storage. Significant differences were detected 
in $\mathrm{O}_{2}$ level at MA75 treatment since the first day of cold storage. The $\mathrm{O}_{2}$ partial pressure reached levels below $1 \%$ (decrease $47 \%$ ) after eight days of cold storage (Figure 1). Probably, the $\mathrm{O}_{2}$ consumption by fruit respiration and the low $\mathrm{O}_{2}$ package permeability for this application, caused the danger anoxia in the fruit, once $1 \% \mathrm{O}_{2}$ is the minimum safe concentration recommended at low temperatures (KADER, 1997). An increase about $20 \%$ in $\mathrm{CO}_{2}$ concentration was verified (Figure 2), exceeding the recommended level for peaches MAP mentioned by Kader (1997).

After 28 days of cold storage, the fruits within the control treatment showed $8.2 \%$ weight loss while those peaches packed in LDPE films reached around $0.20 \%$ and no differences among MAP treatments were detected, confirming previous reports about the properties of the plastic packages on reducing water loss (LURIE, 1993; CHURCH; PARSONS, 1995; GIRARDI et al., 2002; AKBUDAK; ERIS, 2004). After additional 4 days ripening, the control presented approximately $15 \%$ weight loss, due to the transpiration process that caused an excessive water stress, contributing to shrinkage and drying of some fruits. Fruits from MAP treatments reached about 5 to $6 \%$ weight loss and no differences among MA50, MA60 and MA75 were detected. Weight loss to all treatments was higher than that after harvest.

Decay is one of main cause of quality loss in postharvest of peaches and was identified as Monilinia fructicola. MAP had positive influence on decay prevention of 'Douradão' peaches. Fruits from control and MA30 decayed after 28 days cold storage plus ripening, reaching more than 16 and $13 \%$ rotten fruits, respectively, while the other MAP treatments reached about $2 \%$. The high decay incidence might be due the lack of plastic package protection, besides high rates of weight loss might increase decay incidence. These results are supported by reports from others studies on MAP effects on reducing decay (ZOFOLI et al., 1998; AKBUDAK; ERIS, 2004). There were $6 \%$ rotten fruit from MA75 treatment, probably, the anoxia inside the packages induced to fruit fermentation.

The maintenance of fruit in packages with higher $\mathrm{CO}_{2}$ concentrations delayed the rising of SSC which increased slightly along the cold storage period. Peaches from control reached higher levels compared to MAP ones (Table 1). This possibly means that after 28 days cold storage, MAP delayed fruit ripening. After 4 days ripening, a significant increase in SSC was detected under all treatments, with higher increase in fruits from control. Peaches from MA75 reached lower SSC (these fruit produced fermentation) and differed significantly from the others treatments. The SSC from MA30, MA50 and MA60 were similar to that fruits evaluated immediately after harvest. Studies (GIRARDI et al., 2002; AKBUDAK; ERIS, 2004) about cold storage of others peach and nectarine cultivars under MAP support the results obtained on this study with respect to retarding the fruit ripening; the authors mentioned slight changes of SSC during cold storage and higher levels on control fruits when compared to MAP treatments.

Slight or no changes in TA occurred during the cold storage for all treatments. There was no clear influence of MAP on acidity of peaches during cold storage. Probably low temperature reduced the respiration activity and, consequently, the catabolism of organic acids. In general, fruit acidity has been found to decrease and $\mathrm{pH}$ to increase during poststorage ripening. After ripening, a slight decrease in TA was verified from all treatments, without significant differences among them until 21days cold storage plus 4 days additional ripening. After 28 days, the fruits from MA50 and MA60 showed lower values, which were quite lower than that showed by the fruits ripening after harvest (Table 1). Similar results were found during ripening of peaches cultivar Crest Haven stored on MAP (ROBERTSON et al., 1990).

MAP had great influence on flesh firmness after 28 days cold storage. The softening rate of fruits from the Control was proportional to the increase in storage time and weight loss while the peaches packed in LDPE kept higher firmness values and no difference among these treatments were detected. Firmness of the fruits from MA30, MA50 and MA60 treatments were quite similar to that after harvest (Table 2). After ripening, a decrease in flesh firmness was detected for all treatments, with the most significant decrease for the control. There was significant effect of MAP on reducing softening flesh of 'Douradão' peaches from MA50 and MA60 treatments, the values of flesh firmness were higher to these fruits and were similar to that after harvest (fruits not submitted to cold storage). Similar tendency was obtained by Akbudak; Eris (2004) and Seyoung et al. (1997) in their studies on MAP effects on reducing softening flesh of other peaches cultivars.

Just after removing from cold storage, the fruits from control, MA30 and MA75 presented lower juice content while peaches from MA50 and MA60 reached higher ones. The values from these two treatments were similar to that evaluated after harvest (Table 2). With post-storage ripening, similar results were found in which peaches from MA50 and MA60 presented an increase in juice content while 
no increase were observed from the control, MA30 and MA75 treatments.

Woolliness is one of the physiological symptoms of postharvest quality loss in 'Douradão' peaches and it was affected by the MAP treatments. The control treatment presented more than $40 \%$ woolly fruits after 14 days of cold storage and $65 \%$ woolly fruits after $28 \mathrm{~d}$. This fact alone makes the storage strategy economically unfeasible. The use of MAP reduced the occurrence of woolliness; fruits from MA50 and MA60 were little affected, reaching only $6 \%$ woolly fruits after 28 days of cold storage. The fruit from MA30 and MA75 reached, respectively, $54 \%$ and $37 \%$ woolly fruits after the same storage period (Table 2). Several studies about woolliness in peaches and nectarines reported that this condition became apparent by the time the fruits were removed from cold storage and kept at $20-25^{\circ} \mathrm{C}$ (CRISOSTO et al., 1999b; ZHOU et al., 2000a; ROMBALDI et al., 2001). After additional 4 days ripening, Control showed $91 \%$ woolly fruits after 28 days cold storage while the peaches from MA50 and MA60 reached less than $7 \%$. Previous studies reported controlled atmosphere effects on reducing woolliness (ZHOU et al., 2000b; LURIE; CRISOSTO, 2005; GIRARDI et al., 2005). In this study, it was verified that MAP with 50 and $60 \mu \mathrm{m}$ thickness LDPE films, with adequate $\mathrm{O}_{2}$ and $\mathrm{CO}_{2}$ permeability rates at $1 \pm 1{ }^{\circ} \mathrm{C}$, that maintained 1-2 $\mathrm{kPaO}_{2}$ and 3-6 $\mathrm{kPaCO}_{2}$, reduced woolliness in 'Douradão' peaches.

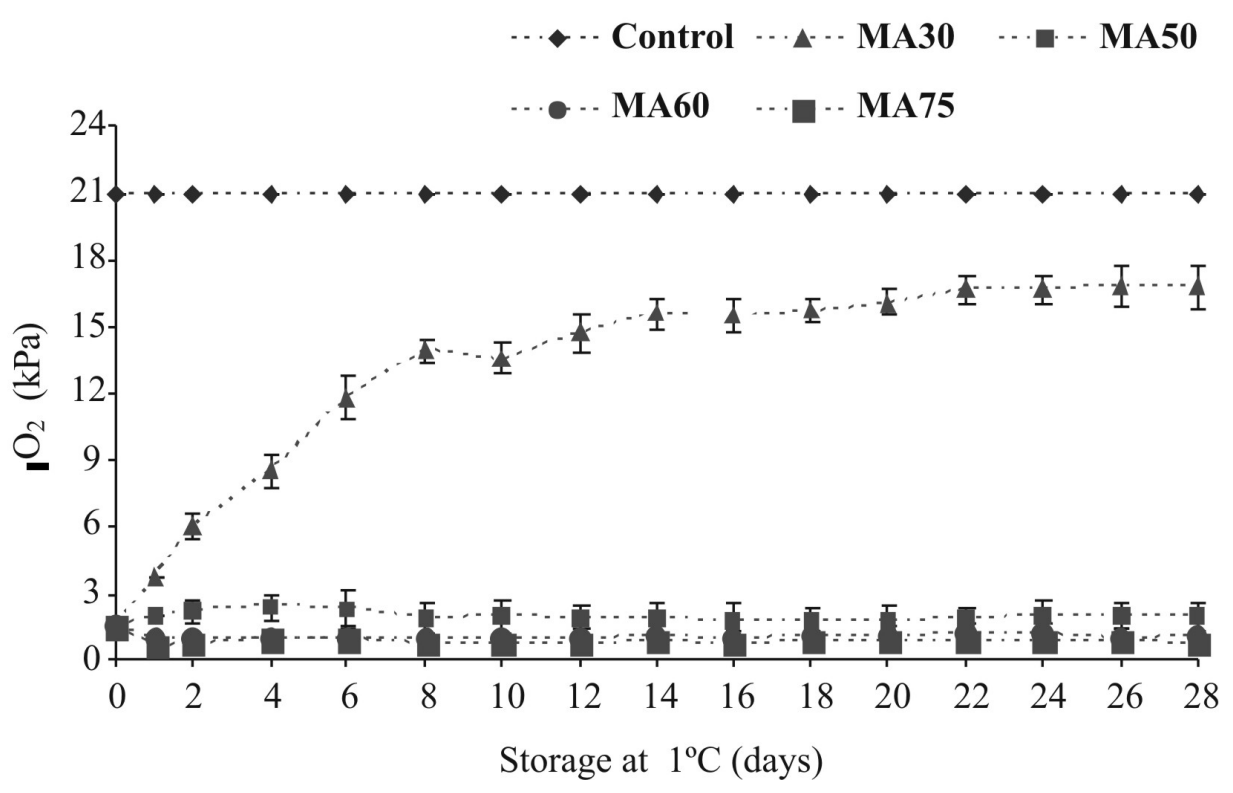

FIGURE 1 - Changes in $\mathrm{O}_{2}$ partial pressure inside modified atmosphere packages of 'Douradão' peaches and control, stored at $1 \pm 1{ }^{\circ} \mathrm{C}$ during 28 days. Standard deviation represented by the vertical $\operatorname{bar}(n=4)$. 


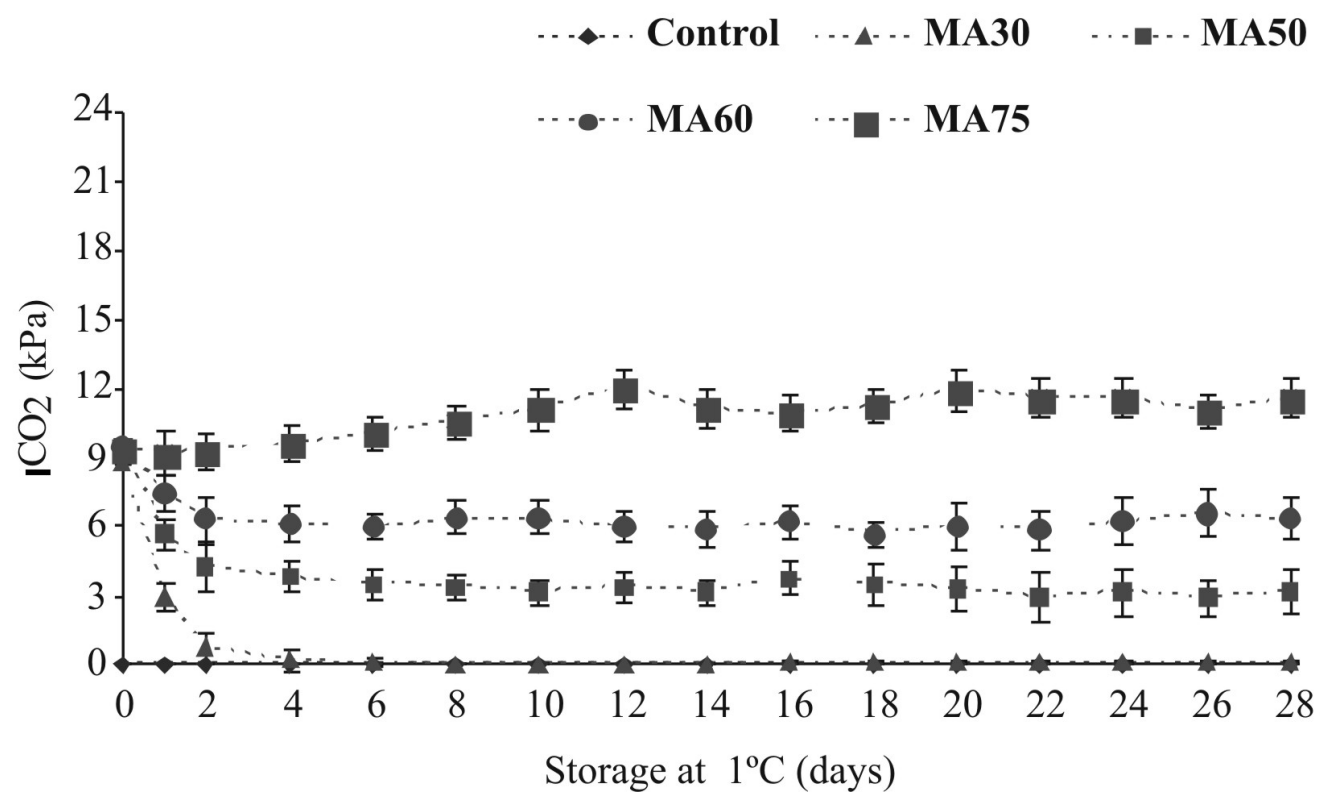

FIGURE 2 - Changes in $\mathrm{CO}_{2}$ partial pressure inside modified atmosphere packages of 'Douradão' peaches and control, stored at $1 \pm 1{ }^{\circ} \mathrm{C}$ during 28 days. Standard deviation represented by the vertical bar $(n=4)$.

TABLE 1 - Soluble solids content and titratable acidity of 'Douradão' peaches after harvest and under MAP after cold storage (CS) at $1 \pm 1{ }^{\circ} \mathrm{C}$ during 14,21 and 28 days, plus 4 days ripening in air at $25 \pm 1^{\circ} \mathrm{C}$.

\begin{tabular}{|c|c|c|c|c|c|c|}
\hline \multirow{3}{*}{ After harvest } & \multicolumn{6}{|c|}{ Soluble solids content $\left({ }^{\circ}\right.$ Brix) } \\
\hline & & $+4 \mathrm{~d}$ ripening & & $+4 \mathrm{~d}$ ripening & & $+4 \mathrm{~d}$ ripening \\
\hline & $9.9^{\mathrm{x}} \pm 1.3^{\mathrm{y}} \mathrm{ab}$ & $12.2 \pm 1.3 \mathrm{~A}$ & $9.9 \pm 1.3 b$ & $12.2 \pm 1.3 \mathrm{~B}$ & $9.9 \pm 1.3 \mathrm{~b}$ & $12.2 \pm 1.3 \mathrm{AB}$ \\
\hline Treatments & After $14 \mathrm{~d}$ CS & $+4 \mathrm{~d}$ ripening & After 21d CS & $+4 \mathrm{~d}$ ripening & After $28 \mathrm{~d}$ CS & $+4 \mathrm{~d}$ ripening \\
\hline Control & $10.8 \pm 1.5 \mathrm{a}$ & $11.7 \pm 2.0 \mathrm{~A}$ & $11.6 \pm 1.9 \mathrm{a}$ & $14.1 \pm 1.4 \quad \mathrm{~A}$ & $11.6 \pm 0.7 \quad \mathrm{a}$ & $13.4 \pm 0.8 \mathrm{~A}$ \\
\hline MA30 & $9.9 \pm 1.2 \mathrm{ab}$ & $11.2 \pm 1.7 \mathrm{AB}$ & $9.9 \pm 0.8 \quad b$ & $11.6 \pm 0.7 \mathrm{~B}$ & $10.6 \pm 0.7 \mathrm{ab}$ & $13.1 \pm 1.0 \mathrm{AB}$ \\
\hline MA50 & $9.2 \pm 1.3 \quad b$ & $11.1 \pm 1.5 \mathrm{AB}$ & $9.6 \pm 1.6 \quad b$ & $11.3 \pm 1.3 \quad \mathrm{BC}$ & $9.9 \pm 0.9 \quad b$ & $11.9 \pm 0.9 \mathrm{~B}$ \\
\hline MA60 & $9.4 \pm 0.5 \quad \mathrm{ab}$ & $11.5 \pm 1.2 \mathrm{~A}$ & $9.5 \pm 0.5 \quad b$ & $11.8 \pm 0.5 \mathrm{~B}$ & $9.9 \pm 0.8 \quad b$ & $12.1 \pm 0.9 \mathrm{AB}$ \\
\hline \multirow[t]{2}{*}{ MA75 } & $8.6 \pm 0.7 \quad b$ & $9.5 \pm 0.8 \mathrm{~B}$ & $8.7 \pm 0.9 \quad$ b & $10.1 \pm 0.7 \mathrm{C}$ & $9.5 \pm 0.4 \quad \mathrm{~b}$ & $10.3 \pm 0.9 \mathrm{C}$ \\
\hline & \multicolumn{6}{|c|}{ Titratable acidity (g malic acid $100 \mathrm{~g}^{-1}$ sample) } \\
\hline \multirow{2}{*}{ After harvest } & & $+4 \mathrm{~d}$ ripening & & $+4 \mathrm{~d}$ ripening & & $+4 \mathrm{~d}$ ripening \\
\hline & $0.3 \pm 0.0 \mathrm{a}$ & $0.3 \pm 0.0 \mathrm{~A}$ & $0.3 \pm 0.0 \mathrm{a}$ & $0.3 \pm 0.0 \mathrm{~A}$ & $0.3 \pm 0.0 \quad \mathrm{a}$ & $0.3 \pm 0.0 \mathrm{~A}$ \\
\hline Treatments & After $14 \mathrm{~d} \mathrm{CS}$ & $+4 \mathrm{~d}$ ripening & After $21 \mathrm{~d} \mathrm{CS}$ & $+4 \mathrm{~d}$ ripening & After $28 \mathrm{~d} \mathrm{CS}$ & $+4 \mathrm{~d}$ ripening \\
\hline Control & $0.3 \pm 0.01 \quad \mathrm{a}$ & $0.3 \pm 0.01 \mathrm{~A}$ & $0.3 \pm 0.01 \mathrm{a}$ & $0.3 \pm 0.01 \mathrm{~A}$ & $0.3 \pm 0.01 \mathrm{a}$ & $0.3 \pm 0.01 \mathrm{~A}$ \\
\hline MA30 & $0.3 \pm 0.01 \quad \mathrm{a}$ & $0.3 \pm 0.01 \mathrm{~A}$ & $0.3 \pm 0.01 \mathrm{a}$ & $0.3 \pm 0.01 \mathrm{~A}$ & $0.3 \pm 0.01 \quad \mathrm{a}$ & $0.3 \pm 0.01 \mathrm{~A}$ \\
\hline MA50 & $0.3 \pm 0.01 \quad \mathrm{a}$ & $0.3 \pm 0.01 \mathrm{~A}$ & $0.3 \pm 0.01 \mathrm{a}$ & $0.3 \pm 0.01 \mathrm{~A}$ & $0.3 \pm 0.01 \mathrm{a}$ & $0.2 \pm 0.01 \mathrm{~B}$ \\
\hline MA60 & $0.3 \pm 0.01 \quad \mathrm{a}$ & $0.3 \pm 0.01 \mathrm{~A}$ & $0.3 \pm 0.01 \mathrm{a}$ & $0.3 \pm 0.01 \mathrm{~A}$ & $0.3 \pm 0.01 \mathrm{a}$ & $0.2 \pm 0.01 \mathrm{~B}$ \\
\hline MA75 & $0.3 \pm 0.01 \quad \mathrm{a}$ & $0.3 \pm 0.01 \mathrm{~A}$ & $0.3 \pm 0.01 \mathrm{a}$ & $0.3 \pm 0.01 \mathrm{~A}$ & $0.3 \pm 0.01 \mathrm{a}$ & $0.3 \pm 0.01 \mathrm{~A}$ \\
\hline
\end{tabular}

${ }^{\mathrm{x}}$ Average and ${ }^{\mathrm{y}}$ Standard deviation

Control $=$ nonwrapped; MA30 $=\mathrm{LDPE30} \mu \mathrm{m} ; \mathrm{MA} 50=\mathrm{LDPE} 50 \mu \mathrm{m} ; \mathrm{MA} 60=\mathrm{LDPE} 60 \mu \mathrm{m} ; \mathrm{MA75}=\mathrm{LDPE75} \mu \mathrm{m}$.

For each parameter, in the column, same letters do not differ significantly between each other, according to Tukey test $(\mathrm{p} \leq 0.05)$. 
TABLE 2 - Flesh firmness, juice content and woolliness incidence of 'Douradão' peaches after harvest and under MAP after cold storage (CS) at $1 \pm 1^{\circ} \mathrm{C}$ during 14,21 and 28 days, plus 4 days ripening in air at $25 \pm 1^{\circ} \mathrm{C}$.

\begin{tabular}{|c|c|c|c|c|c|c|}
\hline \multirow{3}{*}{ After harvest } & \multicolumn{6}{|c|}{ Flesh firmness (N) } \\
\hline & \multicolumn{3}{|c|}{$+4 \mathrm{~d}$ ripening } & \multicolumn{2}{|l|}{$+4 \mathrm{~d}$ ripening } & \multirow{2}{*}{$\begin{array}{c}+4 \mathrm{~d} \text { ripening } \\
5.4 \pm 2.1 \mathrm{AB}\end{array}$} \\
\hline & $52.6^{\mathrm{x}} \pm 2.5^{\mathrm{y}}$ a & $5.4 \pm 2.1 \mathrm{AB}$ & $52.6 \pm 2.5 \mathrm{a}$ & $5.4 \pm 2.1 \mathrm{AB}$ & $52.6 \pm 2.5 \mathrm{a}$ & \\
\hline Treatments & After $14 \mathrm{~d} \mathrm{CS}$ & $+4 \mathrm{~d}$ ripening & After $21 \mathrm{~d} \mathrm{CS}$ & $+4 \mathrm{~d}$ ripening & After $28 \mathrm{~d} \mathrm{CS}$ & $+4 \mathrm{~d}$ ripening \\
\hline Control & $47.3 \pm 6.1 \quad \mathrm{a}$ & $4.7 \pm 1.2 \quad \mathrm{~B}$ & $45.6 \pm 8.5 \mathrm{a}$ & $4.0 \pm 0.7 \mathrm{~B}$ & $32.9 \pm 9.1 \quad \mathrm{c}$ & $3.6 \pm 0.9 \quad \mathrm{~B}$ \\
\hline MA30 & $50.5 \pm 4.9$ a & $5.3 \pm 0.6 \quad \mathrm{AB}$ & $49.5 \pm 7.8 \mathrm{a}$ & $5.1 \pm 0.8 \mathrm{AB}$ & $45.2 \pm 9.8 \quad \mathrm{ab}$ & $4.0 \pm 0.8 \mathrm{AB}$ \\
\hline MA50 & $52.6 \pm 6.5 \mathrm{a}$ & $6.2 \pm 0.5 \quad \mathrm{~A}$ & $51.1 \pm 5.5 \mathrm{a}$ & $6.1 \pm 0.4 \mathrm{~A}$ & $49.7 \pm 7.8 \mathrm{ab}$ & $5.1 \pm 0.3 \mathrm{~A}$ \\
\hline MA60 & $52.5 \pm 2.3 \quad$ a & $6.3 \pm 0.4 \quad \mathrm{~A}$ & $50.9 \pm 6.5$ a & $6.2 \pm 0.9 \mathrm{~A}$ & $49.9 \pm 3.9 \quad \mathrm{ab}$ & $5.2 \pm 0.4 \mathrm{~A}$ \\
\hline \multirow[t]{2}{*}{ MA75 } & $48.3 \pm 5.7 \quad \mathrm{a}$ & $4.7 \pm 0.5 \quad \mathrm{~B}$ & $46.6 \pm 8.4$ a & $4.4 \pm 1.2 \mathrm{~B}$ & $40.4 \pm 8.7 \quad b c$ & $\pm 1.1 \mathrm{AB}$ \\
\hline & \multicolumn{6}{|c|}{ Juice content (\%) } \\
\hline \multirow{2}{*}{ After harvest } & \multirow[b]{2}{*}{$69.0 \pm 3.2 \mathrm{a}$} & ening & & \multicolumn{2}{|l|}{$+4 \mathrm{~d}$ ripening } & ening \\
\hline & & $2.4 \mathrm{~A}$ & $69.0 \pm 3.2 \mathrm{a}$ & $70.5 \pm 2.4 \quad \mathrm{~A}$ & $69.0 \pm 3.2 \mathrm{a}$ & $2.4 \mathrm{~A}$ \\
\hline Treatments & After 14 d CS & $+4 \mathrm{~d}$ ripening & After $21 \mathrm{~d} \mathrm{CS}$ & $+4 \mathrm{~d}$ ripening & After $28 \mathrm{~d} \mathrm{CS}$ & $+4 \mathrm{~d}$ ripening \\
\hline Control & $65.6 \pm 3.9 \mathrm{~b}$ & $66.8 \pm 3.5 \quad \mathrm{~B}$ & $57.7 \pm 2.6 \quad b$ & $58.1 \pm 1.5 \mathrm{C}$ & $49.9 \pm 2.3 \mathrm{c}$ & $50.9 \pm 3.8 \mathrm{C}$ \\
\hline MA30 & $67.6 \pm 1.2 \mathrm{ab}$ & $69.7 \pm 2.9 \mathrm{AB}$ & $58.3 \pm 3.0 \quad \mathrm{~b}$ & $59.7 \pm 1.6 \mathrm{BC}$ & $50.1 \pm 2.6 \mathrm{c}$ & $52.5 \pm 1.6 \mathrm{BC}$ \\
\hline MA50 & $69.7 \pm 1.6 \mathrm{a}$ & $70.8 \pm 2.5 \mathrm{~A}$ & $68.3 \pm 1.5 \mathrm{a}$ & $69.2 \pm 1.1 \mathrm{~A}$ & $66.9 \pm 2.0 \mathrm{ab}$ & $68.6 \pm 1.7 \mathrm{~A}$ \\
\hline MA60 & $69.1 \pm 1.5 \quad \mathrm{a}$ & $70.3 \pm 1.5 \mathrm{~A}$ & $67.9 \pm 0.9 \quad \mathrm{a}$ & $68.7 \pm 1.1 \mathrm{~A}$ & $65.4 \pm 1.7 \mathrm{~b}$ & $67.9 \pm 1.3 \mathrm{~A}$ \\
\hline \multirow[t]{2}{*}{ MA75 } & $68.3 \pm 1.5 \mathrm{ab}$ & $68.4 \pm 1.6 \mathrm{AB}$ & $60.7 \pm 2.9 \quad b$ & $61.2 \pm 1.2 \quad \mathrm{~B}$ & $52.9 \pm 2.8 \mathrm{c}$ & $54.7 \pm 1.6 \mathrm{~B}$ \\
\hline & \multicolumn{6}{|c|}{ Woolliness incidence (\%) } \\
\hline \multirow{2}{*}{ After harvest } & & $+4 \mathrm{~d}$ ripening & & $+4 \mathrm{~d}$ ripening & & $+4 \mathrm{~d}$ ripening \\
\hline & $0.0 \pm 0.0 \mathrm{c}$ & $0.0 \pm 0.0 \quad \mathrm{C}$ & $0.0 \pm 0.0 \mathrm{~d}$ & $0.0 \pm 0.0 \quad \mathrm{C}$ & $0.0 \pm 0.0 \mathrm{~d}$ & $0.0 \pm 0.0 \quad \mathrm{D}$ \\
\hline Treatments & After $14 \mathrm{~d} \mathrm{CS}$ & $+4 \mathrm{~d}$ ripening & After $21 \mathrm{~d} \mathrm{CS}$ & $+4 \mathrm{~d}$ ripening & After $28 \mathrm{~d} \mathrm{CS}$ & $+4 \mathrm{~d}$ ripening \\
\hline Control & $41.7 \pm 4.4 \quad$ a & $43.7 \pm 6.5 \mathrm{~A}$ & $52.1 \pm 3.0$ a & $58.3 \pm 7.2 \mathrm{~A}$ & $64.6 \pm 3.6 \quad \mathrm{a}$ & $91.7 \pm 3.6 \mathrm{~A}$ \\
\hline MA30 & $25.0 \pm 5.2 \mathrm{~b}$ & $20.8 \pm 7.2 \mathrm{~B}$ & $45.8 \pm 6.5 \mathrm{~b}$ & $52.1 \pm 9.5 \mathrm{~A}$ & $54.2 \pm 5.6 \mathrm{ab}$ & $64.6 \pm 3.6 \mathrm{~B}$ \\
\hline MA50 & $0.0 \pm 0.0 \quad \mathrm{c}$ & $0.0 \pm 0.0 \quad \mathrm{C}$ & $0.0 \pm 0.0 \mathrm{~d}$ & $0.0 \pm 0.0 \quad \mathrm{C}$ & $6.3 \pm 0.0 \quad \mathrm{c}$ & $6.3 \pm 0.0 \mathrm{C}$ \\
\hline MA60 & $0.0 \pm 0.0 \mathrm{c}$ & $0.0 \pm 0.0 \quad \mathrm{C}$ & $0.0 \pm 0.0 \mathrm{~d}$ & $0.0 \pm 0.0 \quad \mathrm{C}$ & $6.3 \pm 0.0 \quad \mathrm{c}$ & $6.3 \pm 0.0 \mathrm{C}$ \\
\hline MA75 & $29.2 \pm 7.2 \quad b$ & $20.8 \pm 7.2 \mathrm{~B}$ & $33.3 \pm 6.2 \mathrm{c}$ & $31.3 \pm 6.3 \quad \mathrm{~B}$ & $37.5 \pm 4.8 \mathrm{~b}$ & $54.2 \pm 9.5 \quad$ B \\
\hline
\end{tabular}

${ }^{\mathrm{x}}$ Average and ${ }^{\mathrm{y}}$ Standard deviation

Control $=$ nonwrapped; MA30 $=$ LDPE30 $\mu \mathrm{m} ;$ MA50 $=$ LDPE50 $\mu \mathrm{m} ; \mathrm{MA60}=\mathrm{LDPE60} \mu \mathrm{m} ; \mathrm{MA75}=\mathrm{LDPE75} \mu \mathrm{m}$.

For each parameter, in the column, same letters do not differ significantly between each other, according to Tukey test ( $\mathrm{p} \leq 0.05)$. 


\section{CONCLUSIONS}

MAP had influence on reducing weight loss and prevented postharvest decay; fruit from MAP showed lower SSC and no relevant effect on TA.

MAP of 1-2 $\mathrm{kPaO}_{2}$ and 3-6 $\mathrm{kPa} \mathrm{CO}$ at 1 ${ }^{\circ} \mathrm{C}$, obtained with 50 and $60 \mu \mathrm{m}$ LDPE films, were effective for keeping good quality of 'Douradão' peaches during 28 days of cold storage. The ripe fruits showed reduced incidence of woolliness, adequate juiciness and flesh firmness. Packages of 30 and $75 \mu \mathrm{m}$ LDPE films were ineffective for reducing woolliness during cold storage, due an atmosphere similar to the air surrounding the fruit and an atmosphere with very low oxygen concentration, respectively.

Control fruit did not present marketable conditions after 14 days of cold storage. These fruit presented increasing drastic softening, significant weight loss and decay incidence, higher woolliness index and lower juice content.

\section{REFERENCES}

AKBUDAK, B.; ERIS, A. Physical and chemical changes in peaches and nectarines during the modified atmosphere storage. Food Control, Oxford, v. 15, n. 2 , p. $307-313,2004$.

ASAE - American Society of Agricultural Engineers. Agricultural engineers yearbook of standards. 16.ed. St. Joseph, 2000.

AOAC - Association of Official Analytical Chemists. Official methods of chemists analysis. 17. ed. Arlington 1995. $1141 \mathrm{p}$.

BASSETTO, E. Quantificação de danos ao longo da cadeia produtiva de pêssegos e avaliação de métodos alternativos de controle de doenças pós-colheita. 2006. 125 f. Tese (PhD Agronomia) - Escola Superior de Agricultura "Luiz de Queiroz" - Universidade de São Paulo, Piracicaba, 2006.

CHURCH, I.J.; PARSONS, A.L. Modified atmosphere packaging technology: a review. Journal Science Food Agricultural, Chicago, v. 67, n. 4, p. 143-152, 1995.

CRISOSTO, C.H.; GARNER, D.; CID, L.; DAY, K.R. Peach size affects storage, market life. California Agricultural, California, v. 53, n.1, p. 33-36, 1999a.
CRISOSTO, C.H.; JOHNSON, R.S.; DEJONG, T.; DAY, K.R. Orchard factors affecting postharvest stone fruit quality. HortScience, Alexandria, v. 32, n. 4, p. 820-823, 1997.

CRISOSTO, C.H.; MITCHELL, F.G.; JU, Z. Susceptibility to chilling injury of peach, nectarine and plum cultivars grown in California. HortScience, Alexandria, v. 34, n. 1, p. 1116-1118, 1999 b.

DEILY, K.R.; RIZVI, S.S.H. Optimisation of parameters for packaging of fresh peaches in polymeric films. Horticultural Abstract, Wageningen, v. 53, n. 6, p. 4886-4887, 1983.

FERNÁNDEZ-TRUJILLO, J.P.; CANO, A.; ARTÉS, F. Physiological changes in peaches related to chilling injury and ripening. Postharvest Biology and Technology, Wageningen, v. 13, n.1, p. 109119, 1998

GIRARDI, C.L.; CORRENT, A.R.; LUCCHETTA, L.; ZANUZO, M.R.; COSTA, T.S.; BRACKMANN, A.; TWYMAN, R.M.; NORA, L.; SILVA, J.A.; ROMBALDI, C.V. Effect of ethylene, intermittent warming and controlled atmosphere on postharvest quality and the occurrence of woolliness in peach (Prunus persica cv. Chiripá) during cold storage. Postharvest Biology and Technology, Wageningen, v. 38, n. 1, p. 25-33, 2005.

GIRARDI, C.L.; PARUSSOLO, A.; DANIELI, R.; CORRENT, A.R.; ROMBALDI, C.V. Armazenamento de pêssegos (Prunus persica (L) Batsch) cv. Chiripá em atmosfera modificada. Revista Iberoamericana Tecnología Postcosecha, Mexico, v. 4, n. 2, p. 128-133, 2002.

HARRIS, C.M.; HARVEY, J.M. Quality and decay of California strawberries stored in $\mathrm{CO}$ enriched atmospheres. Plant Diseases Reporter, Copenhagen, v. 57, n. 2, p. 44-46, 1973.

KADER, A.A. A summary of CA requirements and recommendations for fruit other than pome fruit. In: INTERNATIONAL CONTROLLED ATMOSPHERE RESEARCH CONFERENCE, 7. 1997, Davis. Proceedings...

LURIE, S. Modified atmosphere storage of peaches and nectarines to reduce storage disorders. Journal of Food Quality, Trumbull, v. 16, n. 2, p.57-65, 1993. 
LURIE, S.; CRISOSTO, C.H. Chilling injury in peach and nectarine. Postharvest Biology and Technology, Wageningen, v. 37, n.1, p. 195-208, 2005.

ROBERTSON, S.A.; MEREDITH, F.I.; HORVAT, R.S.; SENTER, S.D. Effect of cold storage and maturity on the physical and chemical characteristics and volatile constituents of peaches cv Crest Haven. Journal Agriculture Food Chemistry, Easton, v. 38, n.1, p. 620-624, 1990.

ROMBALDI, C.V.; SILVA, J.A.; MACHADO, L.B.; PARUSSOLO, A.; KASTER, L.C.; GIRARDI, C.L.; DANIELI, R. Harvesting stage and cold storage influences on the quality of Chiripá peaches (Prunus persica L). Ciência Rural, Santa Maria, v. 31, n. 2, p. 19-25, 2001.

SEYOUNG, O.; SEUNGSIK, S.; CHONGCHON, $\mathrm{K}$. Effect of packaging films and freshness keeping agents on fruit quality of Yumyung peaches during MA storage. Postharvest News and Information, Amsterdam, v. 8, n. 4, p. 1611-1616, 1997.

SAS - Statistical Analysis System. User's procedures guide. Version 6. Cary: SAS Institute, 2003. 2v

VON MOLLENDORFF, L.J. Woolliness in peaches and nectarines: A review. 1. Maturity and external factors. Journal of Horticultural Science, Ashford, v. 5, n. 1, p.1-3, 1987.
VON MOLLENDORFF, L.J.; DE VILLIERS, O.T. Physiological changes associated with the development of woolliness in "Peregrine" peaches during low-temperature storage. Journal of Horticultural Science, Ashford, v. 63, n. 1, p. 4751, 1988.

ZHOU, H.; BEN-ARIE, R.; LURIE, S. Pectin esterase, polygalacturonase and gel formation in peach pectin fractions. Phytochemistry, Oxford, v. 55, n.2, p. 191-195, 2000a.

ZHOU, H.; LURIE, S.; LERS, A.; KHATCHITSKI, A.; SONEGO, L.; BENARIE, R. Delayed storage and controlled atmosphere storage of nectarines: two strategies to prevent woolliness. Postharvest Biology and Technology, Wageningen, v. 18, n. 1, p. 133-141, 2000b.

ZOFFOLI, J.P.; ALDUNCE, J.R.P.; CRISOSTO, C.H. Modified atmosphere in fruits of Elegant Lady and Ohenry peaches. Postharvest News and Information, Amsterdam, v. 9, n.3, p. 1000-1005, 1998.

ZOFFOLI, J.P.; RODRIGUEZ, J.; ALDUNCE, J.R.P.; CRISOSTO, C.H. Development of high concentration carbon dioxide modified atmosphere packaging systems to maintain peach quality. In: INTERNATIONAL CONTROLLED ATMOSPHERE RESEARCH CONFERENCE, 7., 1997, Davis. Proceedings... 